\title{
O GROTESCO DA SECA
}

Patrícia Gomes Germano é natural de Aroeiras (PB), é professora da Rede Pública Estadual de Ensino, doutoranda no Programa de Pós-graduação em Literatura e Interculturalidade da Universidade Estadual da Paraíba, pesquisadora da Capes/CNPQ, desenvolve trabalhos de formação de professores em cursos de Especialização e Mestrado Profissionalizantes além de ser autora do blog: arquipelagopgg.blogspot.com em que disponibiliza aos internautas um pouco de poesia.

E-mail: patriciagomesgermano@gmail.com

A seca é uma grande boca

Que devora as esperanças do mundo.

A seca é um ventre disforme

Que deglute, em suas insaciáveis entranhas,

Homens despedaçados...

Com sua desmesurada fome,

Alimenta-se da força, do trabalho e dos sonhos.

E deixa o mundo um prato vazio...

E deixa os lagos, bacias rasas de findas águas,

Os rios, ressequidas veias de sugado sangue,

Os sobreviventes, multidão cambaleante

De sedentos Pantagruéis...

De suas entranhas férvidas,

A Terra, quando em "regras" de seca,

Sua todo o salgado do mar

Aliviando-se de seus noturnos e caudalosos calores.

Os sobreviventes, gargantas agigantadas,

Rostos boquiabertos;

Definham e deslizam, à espera

de lágrimas fecundas

Derribadas de um céu, virilmente semeador. 